\title{
The Consequences of Divorce and Splitting up for Spatial Mobility in the UK
}

\author{
Peteke Feijten, Maarten van Ham
}

\begin{abstract}
Union dissolution is well known to have a disruptive effect on the housing situation of those involved, and often leads to downward moves on the "housing ladder". Much less is known about the geographies of residential mobility after union dissolution. There are, however, reasons to expect that those who experienced a union dissolution have a different likelihood of moving over longer distances than those who stay in a union, because of different moving motives. This study contributes to the existing literature by investigating the occurrences of moves, distances moved and the destinations of moves after union dissolution. The paper also contributes to the literature by investigating the effect on mobility not only of divorce, but also of splitting up and repartnering. Using longitudinal data from the British Household Panel Survey (BHPS), and logistic regression models, we found that union dissolution has a significant effect on the occurrence of moves and on moving distances.
\end{abstract}

Keywords: Union dissolution · Splitting up - Divorce $\cdot$ Housing career $\cdot$ Spatial mobility $\cdot$ Longitudinal data $\cdot$ BHPS $\cdot$ United Kingdom

\section{Introduction}

Since the 1960s, there has been a large increase in divorce rates in most of the Western world. The annual number of divorces in the United Kingdom increased from 25,000 in 1960 to almost 150,000 in 1980. The number has stayed around this level ever since. As a consequence of the rise in divorce rates, an increasing proportion of all marriages now includes at least one previously-divorced partner. Of all

\footnotetext{
An earlier version of this paper was published as an IZA working paper (No. 5628) under the title "The Impact of Union Dissolution on Moving Distances and Destinations in the UK" (Feijten/van Ham 2011).
} 
men who married in the UK in 2007, 27 percent were previously divorced, against 22 percent in 1980 and 9 percent in 1970 (ONS 2007a). Divorce has thus become a common life event for a significant percentage of the population.

In this study, we take a broad view on union dissolution, and include both divorce and the dissolution of non-marital unions, to which we will refer as "splitting up". Unmarried cohabitation has become a precursor to marriage for many people. The majority of cohabitees whose cohabitation is successful will eventually proceed to marriage. A smaller group remains unmarried, and these cohabitations are more permanent and have the same durable character as a marriage (Kiernan/Estaugh 1993). No official statistics are available on the number of cohabiting unions and subsequent split ups (because cohabitation is an unregistered living arrangement in the UK). We do, however, know from survey research that the number of unmarried cohabiters has increased considerably in recent decades. A commonly used indicator of this trend is the sharp rise in live births to unmarried mothers as a percentage of all live births (Bumpass/Lu 2000), from about 6 percent in 1960 to more than 41 percent in 2005 (ONS 2007b). Unmarried cohabitation has now partly replaced marriage as a durable form of living together.

In the late 1980s and 1990s, when the high divorce rates became consolidated, a number of studies investigated the effects of divorce on housing careers (Sullivan 1986; Schouw/Dieleman 1987; Clapham et al. 1993; Jackson 1990; Murphy 1990; Symon 1990; Wasoff/Dobash 1990; Watchman 1990; McCarthy/Simpson 1991; Van Noortwijk et al. 1992). These studies showed that divorce has a disruptive effect on the housing careers of those involved, often leading to downward moves on the housing ladder (Feijten 2005a/b): moves from large to smaller and lower quality dwellings, moves from owner-occupation into rented housing and from single-family dwellings into multi-family dwellings (see Feijten/van Ham 2010 for a recent study using UK data). Similar effects were found for the split up of non-marital unions, although the effects were less severe than for the divorced (Feijten 2005a/b).

An aspect of post-divorce and post-split up housing careers that received much less attention is the spatial mobility of those involved in union dissolution (recent exceptions are Flowerdew and Al-Hamad 2004 for the UK; and Feijten and van Ham 2007 for the Netherlands). There are good conceptual reasons to believe that union dissolution has an effect on the occurrence of moves, distances moved and the moving destinations of those involved because moves triggered by divorce are deviant compared to moves triggered by other life events. For people who have children from a previous relationship, there is an extra element that might influence spatial behaviour: They are likely to have a desire to stay in close proximity to the home of their ex-partner for the sake of (contact with) their children. This seriously limits their spatial mobility choices. Repartnering can lead to even more complicated spatial arrangements and constraints when both partners in a household have children from previous unions. Such situations may seriously reduce the willingness of people to move over longer distances (beyond the usual factors for lowering long distance moves in this life course phase, such as having a secure job, and increasing age). On the macro level, this may reduce workers' spatial flexibility. 
This paper will contribute in three ways to the existing literature on the effects of union dissolution on housing careers (the term "career" having a neutral meaning denoting sequences of events over the life course). Firstly, it will focus solely on spatial aspects of housing careers, including the occurrence of moves, distances moved, and the destinations of moves after union dissolution. Secondly, we will take into account the rise in cohabitation and study the effect of both splitting up and divorce on spatial mobility. Thirdly, we will look at the effect of repartnering on spatial careers.

\section{Background}

\section{Union dissolution, housing and mobility}

The effects of divorce on housing careers are well documented. Clapham and colleagues (1993) found that, after separation and divorce, men were more successful in staying in owner-occupation than women (50 versus 44 percent, see also Symon 1990). Helderman (2007) showed that for the Netherlands over the period 1981-2002, the most common reason for moving from owner-occupation into rented housing was divorce/separation, especially for women. Twice as many moving divorcees reported a decrease in the number of rooms than reported an increase (Wasoff/Dobash 1990). Lack of amenities was twice as common among divorced women compared to married women (Murphy 1990); those divorced women were often childless, and the lack of amenities was frequently associated with living in the private rented sector. Divorced people were also reported to live less often in single family dwellings than married families, even when the presence of dependent children was controlled for (Sullivan 1986; Murphy 1990). A recent study using data from the British Household Panel Survey (BHPS) confirmed that union dissolutions have severe implications for housing careers in the UK (Feijten/van Ham 2010). The opposite has been studied as well: whether married or cohabiting people who often move are more likely to break up (Boyle et al. 2008). Using a method for jointly estimating the events of union dissolution and moving, their model allowed for both directions of causality, and it was found that moving (especially long-distance moving) has an effect on the risk of union dissolution. In this paper, however, we look particularly at moving behaviour in the period after union dissolution, which, because of the chronological sequence, can only indicate an effect of union dissolution on mobility.

Several studies have shown that it takes a series of moves before divorced people once more live in housing they see as suitable (McCarthy/Simpson 1991; Watchman 1990; Jackson 1990). McCarthy and Simpson (1991) found that 20 percent of their sample of 1,122 people made more than two moves in the period after separation (up to three years after divorce). Divorcees with dependent children made fewer moves (a maximum of five) than those without dependent children (some of whom made more than eight moves). Wasoff and Dobash (1990) found different effects of union dissolution on housing at the moment of separation, the period between separation and divorce, the moment of divorce, and the post-divorce period. 
The initial separation was found to lead to a move by one of the partners, and in some cases by both. In the period between separation and the divorce settlement, the majority of people moved house at least once, and often more than once.

A limited number of studies has also investigated the spatial aspects of housing careers after union dissolution. Feijten and Van Ham (2007) showed for the Netherlands that, directly after a union dissolution, people move more often than people in other living arrangements. Although their mobility rate decreased over time, it remained higher than that of their married counterparts for several years after the event. A study by South and Crowder (1998) used data from the US to show that children in post-divorce families moved to significantly poorer neighbourhoods than children in intact two-parent families. These were often moves from suburbs to city centres (which in the American context often equates to moving to poorer areas). This was mainly attributable to differences in economic resources between these types of families. A study by Feijten et al. (2008) showed for the Netherlands that those who were divorced, or who had split up, were more likely to move to the cities than people with other marital statuses, and less likely to move to rural areas. An older study for Germany (Kemper 1985) also found that divorced men and women were more likely to move to city centres than others. Feijten and Van Ham (2007) found for the Netherlands that people moved over shorter distances after a union dissolution than others, especially shortly after the break up. They also found that people were more likely to move into the cities after a union dissolution, and to stay in cities once they lived there, than married people (Feijten/Van Ham 2007).

\section{Why divorce and splitting up can be expected to affect spatial mobility}

There is a close relationship between household and housing careers in the life course. Life events such as getting married and having children often coincide with upward moves on the housing ladder (Rossi 1955; Brown/Moore 1970; Michelson 1977; Mulder/Hooimeijer 1999; Feijten 2005b). The split up of unmarried couples or the divorce of married couples inevitably results in major changes in the household configuration and subsequently in changing requirements with regard to the dwelling and the location of the dwelling. There are several reasons why splitting up and divorce can be expected to have implications for the housing career. This is because moves triggered by union dissolution are deviant compared to those triggered by other life events. Moves triggered by union dissolution are: 1) urgent, 2) financially restricted, and 3) spatially restricted (Feijten/Van Ham 2007; see also Feijten/van Ham, 2010). Because those involved in a decision to split up or to have a divorce usually want to put that decision into effect as soon as possible, subsequent moves are urgent. As a result, most people simply have to accept the first available housing option, which is often suboptimal. It can then take several moves before they are able to find accommodation which they see as suitable. Moves triggered by union dissolution are also financially restricted because they often coincide with a decline in resources, especially when personal income is lower than the previous household income (Jarvis/Jenkins 1999; Poortman/Fokkema 2001; Aassve et 
al. 2006). This leads us to expect that divorced and split up people move more often than married and cohabiting people (Hypothesis 1).

Moves triggered by union dissolution can also be expected to be spatially restricted (Feijten/Van Ham 2007). A study by Symon (1990) reported that after a union dissolution, some people were intentionally looking for accommodation in a different area, to make a fresh start, to move back to the area where family and (old) friends live, to avoid contact with the ex-spouse and/or his/her family, or to move away from a place filled with bad memories (see also Jackson 1990; Watchman 1990). Anthony (1997), on the other hand, found that some people desperately wanted to stay in their matrimonial home because they said it was filled with memories of better times. Others prefer to stay close to the former matrimonial home for employment reasons and nearness to friends and family. Location-specific capital (DaVanzo 1981) can be a lifeline for people who are suddenly on their own after a union dissolution, and feelings of attachment to a place (Feldman 1990; Winstanley et al. 2002) may be particularly strong after a divorce.

When a couple has (young) children, and both parents are committed to taking shared responsibility for the upbringing, moves after a union dissolution are severely spatially restricted. Custody of the children is usually granted to one of the partners (mostly the mother), and some meeting arrangement is agreed for the other parent. For the sake of the children, the couple often decides that the partner who gets custody stays in the matrimonial home, but if that is not possible, the preference to stay close to the matrimonial home is often very strong in order to change as little as possible in the children's daily life. For non-custody parents, living close to where the children live can be essential for maintaining a close bond with them. It has been found in Danish data that non-custody fathers live at a significantly closer distance to their children than childless men live to the home of their ex-partner (Gram-Hanssen 2006). It was found in a study for the Netherlands that the mean distance moved by divorced people is shorter than that of people who have never married and people in a first relationship. In particular divorced men with children were found to move over short distances (Feijten/Van Ham 2007). A recent quantitative study from Sweden found that many divorcees whose children live with the other parent continue to live close to their children. Of all non-residential fathers, 84 percent lived within 50 kilometres from their children (Stjernström 2009a). An accompanying qualitative study (Stjernström 2009b) showed that parents of young children often found it important to live at a very close distance (walking distance). Feelings of guilt towards the child(ren) were a major motivation behind this, together with a longing to maintain a very close bond with the child(ren). Evidence from Norway (Barlindhaug/Skjørten 2007) suggests that joint custody arrangements (where the children live one half of the week with their mother and the other half of the week with their father) lead to ex-partners living close together, where in 50 percent of the cases they live within walking distance (and within a maximum travel time of half an hour in 96 percent of cases). This seriously limits the residential choice set for jointcustody parents, and even more so for those who have repartnered with someone who also has children from a previous relationship (Barlindhaug/Skjørten 2007). Although we have presented arguments predicting greater moving distances as 
well as arguments predicting shorter moving distances after union dissolution, we expect overall that divorced and split up people move over shorter distances than married and cohabiting people; this is expected to be especially true for divorced/ split up parents (Hypothesis 2).

Many married couples, especially those with children, live in suburban neighbourhoods with a mono-residential function, where attributes such as a large-sized home and garden space, easy access to schools and convenience shops, and a short driving distance to motorways, are important. These elements may become less important after a divorce. Elements such as the availability of affordable (smaller, rented) housing, a lively and anonymous living environment, closeness to a large supply of jobs and a large pool of potential new partners may become more important. Urban environments offer these attributes, and thus cities can be expected to attract divorcees, in favour of suburbs and rural areas. Thus we expect that divorced and split up people move to cities more often than married and cohabiting people (Hypothesis 3).

Lastly, entering a new household type after union dissolution may generate a shift in preferences concerning the residential environment. When people find a new partner after splitting up or divorce, their circumstances, desires and needs may change again. Repartnering often leads to an increase in household resources, especially for women (Dewilde/Uunk 2008; Coleman et al. 2000). Residential preferences may change due to an increased household size, and partly due to lifestyle changes. This leads us to expect that the location choices of those who repartner after union dissolution will resemble those of married people, but that their spatial behaviour will be restricted if there are children from the previous relationship. The above leads us to expect that people in a new relationship move less often, over longer distances, and move less frequently into cities than the divorced/separated (Hypothesis 4).

\section{Data and Method}

\section{Data}

The data analysed are from the British Household Panel Survey (BHPS), which is a nationally representative stratified sample of 5,500 households $(10,300$ interviewed individuals) drawn from 250 areas of Great Britain in 1991. Additional booster samples for Scotland, Wales and Northern Ireland were added later, but we only use the original 1991 sample for this study. The same individuals have been re-interviewed on a large number of topics in each successive year since 1991. We have used a panel of 14 years for our analyses, and we have only used respondents who were the head of the household or the partner of the head of the household. We excluded person-years over age 70 (because the elderly have a different moving pattern altogether), person-years of widowhood (because they constitute a different category of marital status which is beyond the scope of this paper), and person-years when people were in full-time education (because they usually have not yet started 
their independent housing careers). Lastly, we excluded respondents on whom too much background information was missing (such as income and housing tenure), or whose move status was unknown. ${ }^{1}$ The remaining sample contains 74,711 personyears representing 8,800 respondents. The number of years in which respondents in our sample are observed ranges from one year (9.7 percent of respondents) to 13 years (34.1 percent of respondents).

In the first few waves of the BHPS, people were interviewed about their life histories until the start of the panel, such as their fertility and relationship history. This allowed us to calculate the duration of the marital status that they had in the first wave (and adjust this timevaryingly in the successive panel years). The retrospective information also allowed us to determine whether people in the $1^{\text {st }}$ wave who had never married had cohabited in the past, and therefore had to be categorised as "split up" in wave 1. And whether married people were in a higher order marriage in the $1^{\text {st }}$ wave, and therefore had to be categorised as "in a new relationship" in wave 1. Completed fertility histories meant that we could identify parents whose children do not live in their household (mostly non-custody fathers and a few noncustody mothers). A potential problem when studying mobility with panel data is that those who move are more likely to leave the panel compared to those who stay. Buck (2000) has shown that although this problem is present in the BHPS, its effect on the study of residential mobility and migration is limited because only a small percentage of movers disappear without leaving any information. However, there is a risk that those who disappear from the panel are disproportionately people who recently separated/divorced or split up. This would lead to an undercounting of divorcees/split-up people, but it does not necessarily bias the results because there is no obvious reason to think that divorcees who leave the panel behave differently than divorcees who stay in the panel.

\section{Variables}

The table in Appendix 1 lists all the variables used in the analyses and gives selected summary statistics. A few of these variables need some additional explanation. The living arrangement variable was created by using marital status and comparing this in each wave with the relationship history (including relationship history before the start of the panel - see previous section). This allowed us to determine dissolutions of cohabiting unions and of married unions. It also allowed us to determine when people entered a new union, either right upon split up or divorce, or after a spell of being single after a union dissolution. This resulted in six living arrangement categories:

1. married (in a first marriage);

1 Because mover status is derived by comparing the current place of residence and the previous place of residence (one year ago), move status was unknown for everyone in the first year of the panel. All observations from 1991 were discarded as a result of this. 
2. never married (lives alone and has not been married or cohabited, also not before the start of the panel);

3. cohabiting (in a first cohabiting relationship with an unmarried partner);

4. divorced (lives alone after separation or divorce from the marriage partner);

5. split up (lives alone after splitting up from an unmarried partner);

6. new relationship (lives in cohabiting or married union and has previously been in a union (either cohabiting or married), either before or during the panel).

For those who were in a union at the time of the first wave, the relationship duration was calculated using the reported start year of the marital status. If people changed marital status during the panel, the duration count started again at zero. For the people who were not in a union in the $1^{\text {st }}$ wave, it was not possible to calculate a duration. To solve this problem statistically, we created a dummy indicating a missing value on duration, and we substituted the actual missing duration score for the mean duration of all other cases (Cohen/Cohen 1975). We used the same technique for the handful of people who did not report the starting date of their current marital status.

The lowest geographical level that can be analysed using the BHPS without a special licence are the 434 Local Authority Districts (LADs). For reasons of data confidentiality, LADs were aggregated if their population was below 120,000, which resulted in 277 LAD areas that can be analysed in the BHPS. We labelled each LAD as "urban" or "rural", based on a multiple-item area classification developed by the Office of National Statistics. We also attached the variable "distance moved" to our data. Distance was calculated by the BHPS team using distances between centroids of wards (low spatial level units ( $N=8855)$, each comprising on average 600 people), and is expressed in kilometres.

\section{Method}

We study the following aspects of housing and mobility after union dissolution: Occurrence of moving (How often do people in certain living arrangements move?); and for those who move the distance moved and the likelihood of moving to a city. For each aspect, we first analyse the association with living arrangement in a base model, which does not control for other factors. We then add duration of living arrangement and then control for the usual individual and household background variables. The risk of moving is analysed in a logistic panel model because panel models are apt to capture the time dimension of being at risk from experiencing a move. Once we know the risk structure of moving for people in different living arrangements, we subsequently analyse movers only.

Distance moved is analysed using OLS regression. Moving distance is not normally distributed as many people move very short distances and few people move long distances. The use of OLS with a dependent variable which is right skewed is suboptimal. The residuals of the OLS model more closely approach a normal 
distribution, but are also right skewed. This suggests that the model is less capable of predicting long distances than short distances. We still prefer to use OLS as the alternatives are also suboptimal. One such alternative is to use a transformation of the dependent variable (distance) using a LOG function. The LOG of distance more closely approaches a normal distribution, but has a major disadvantage, namely that the tail on the right-hand side of the distribution is reduced, narrowing the spread of values. Modelling moving distance using the LOG of distance is therefore less suitable for our purposes in our opinion, as we are interested in long-distance moves as well. It is important to note that the outcomes of models using the LOG of distance are globally robust compared to the OLS models without transformation. Another alternative is to dichotomise the dependent variable distance. This however reduces the amount of information available and does not do justice to the phenomenon being researched. We therefore rejected this option. A final alternative is to use a different model distribution function such as Poisson. However, Poisson is suitable for phenomena with low counts and low means, but unsuitable for data with a large number of counts and with a larger mean, as in our case. The use of OLS is preferable in these cases (MacDonald/Lattimore 2010).

The event of moving to a city (for those living in non-urban Local Authority Districts) is analysed using a logistic regression model. Because of the possibility of several moves per person in the sample, the standard errors in our models are corrected for non-independent observations using the Huber-White estimator (Huber 1967).

\section{$4 \quad$ Results}

\section{Moving occurrence}

We expected that divorced people would move more often than their married counterparts, and that people who split up would move more often than their cohabiting counterparts (Hypothesis 1). The results from Model 1 in Table 1 support the first part of the hypothesis, but not the second. Those who have split up are as likely to move as those who cohabit. Once we control for duration of the living arrangement in Model 2, the main effects become less pronounced, but remain positive and significant. Duration of living arrangement has a negative effect on the probability of moving: The longer one is in a certain living arrangement, the lower is the likelihood of moving. After controlling for durations in Model 2, divorced people are still 1.5 times more likely to move than married people (exp(0.42)).

To check whether the effect of duration on the probability of moving works out differently for people in different living arrangements, we interacted living arrangement with duration (see Model 3 in Table 1). This model also controls for a range of variables known to affect the probability of moving. All the effects of these control variables are as expected based on the relevant residential mobility literature. The main effects and interaction effects of living arrangement and duration are plotted in Figure 1 as relative risks. As in Table 1, the married are the reference category, 


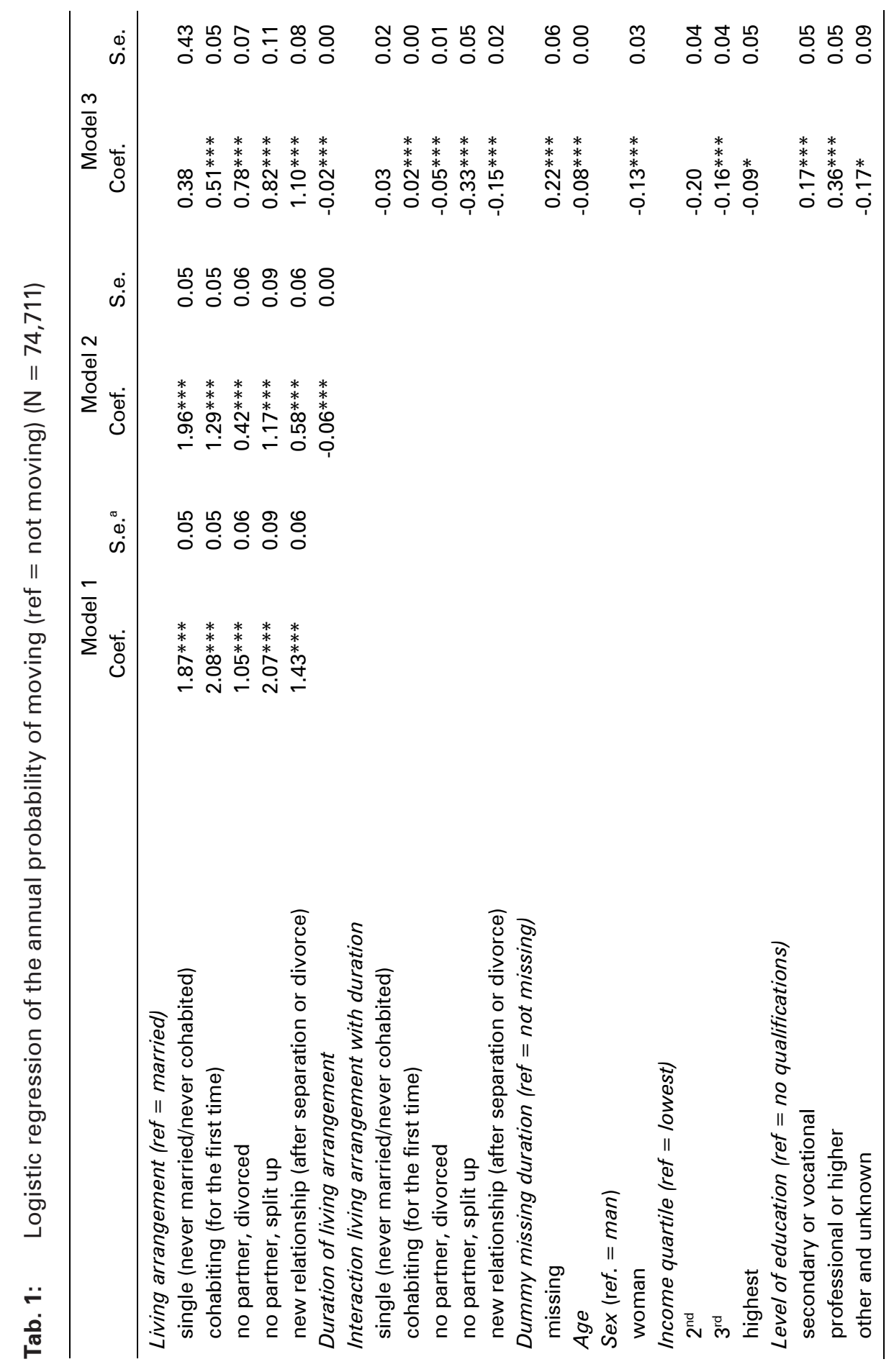




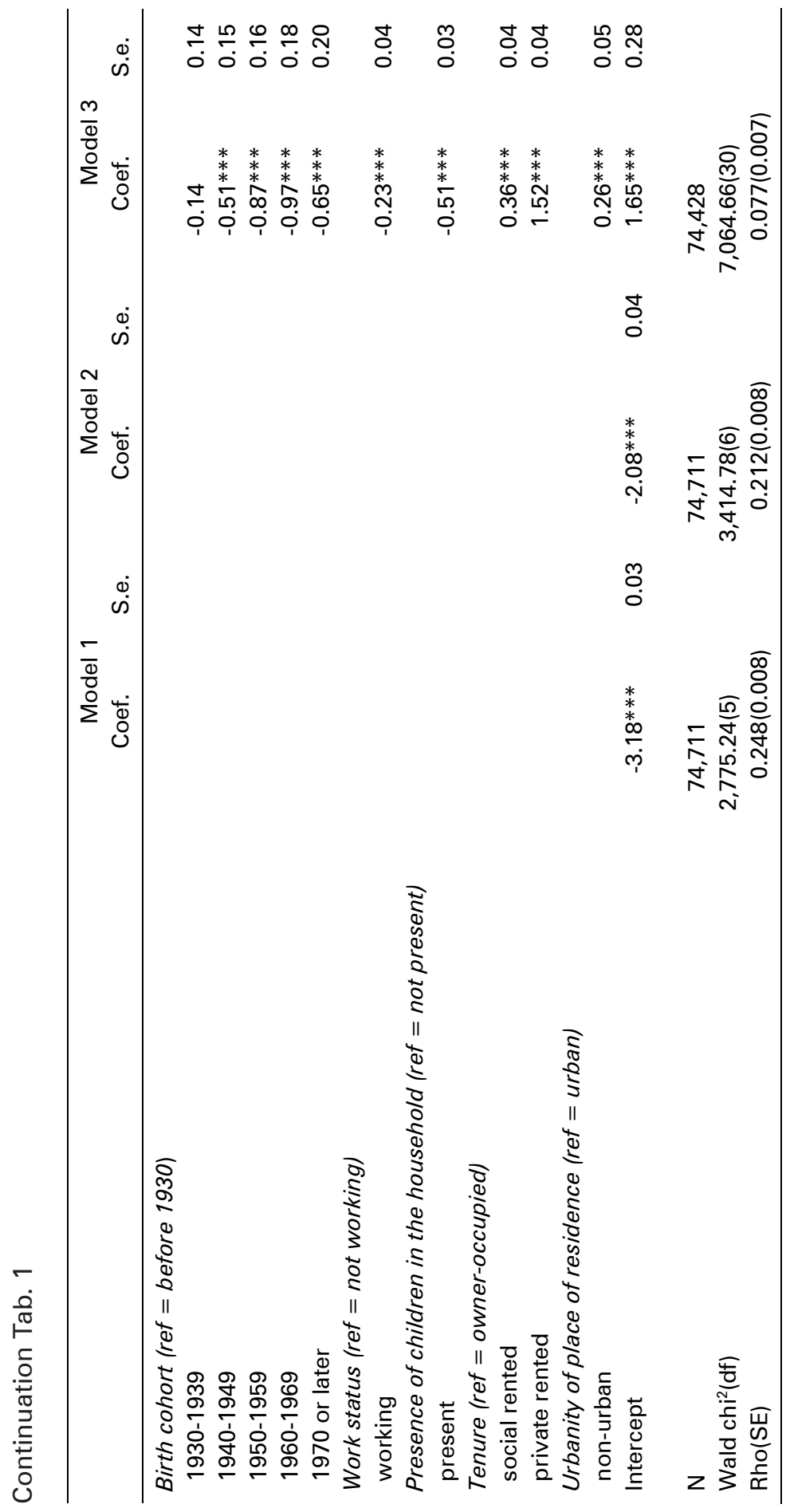

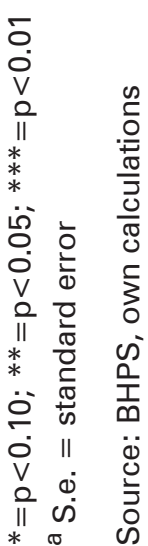


Fig 1: $\quad$ Estimated annual risk of moving, by relationship type and duration (based on Model 3 of Table 1) $(\mathrm{N}=3,242)$

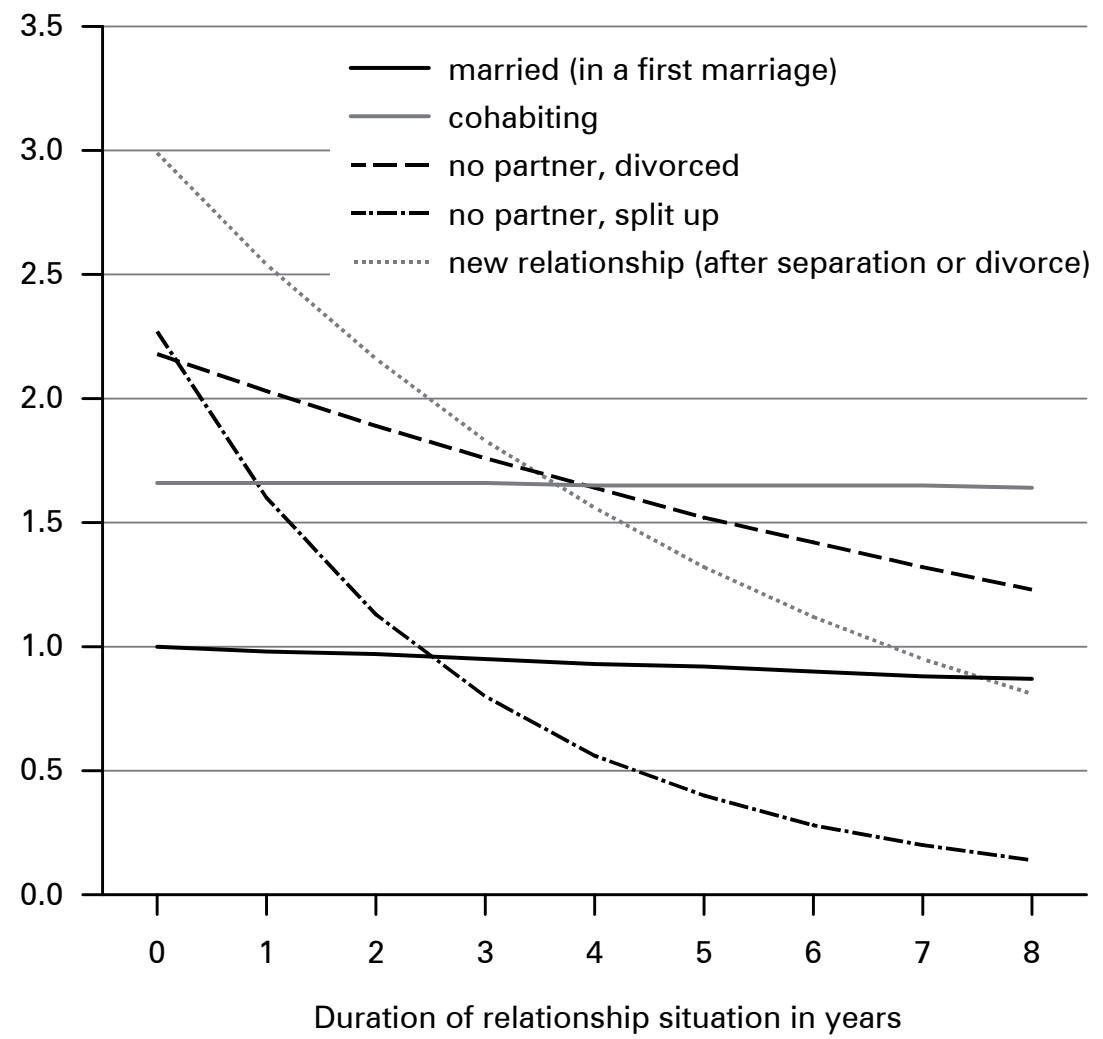

Source: BHPS, own calculations

and thus their relative risk of moving is 1 in the start year. It can be seen that the pace at which moving probability decreases with duration is very different for the five relationship types. The split up and divorced people start off higher than those who are cohabiting and married, but the probability of moving decreases quickly with duration, ${ }^{2}$ especially for those who split up. The probability of moving for the divorced decreases much slower, and as a result it is one of the highest at durations over three years. Only cohabiters have a higher moving probability, and one which is remarkably stable over time, and much higher than for those who split up. The findings lend support to our hypothesis that many people enter a period of frequent mobility after divorce. Even eight years after the divorce, the estimated moving probability for the divorced is still higher than for the married. Re-partnering after divorce lowers the probability of moving, albeit not immediately: The probability

2 The lines plotted for durations are based on estimates for people who have continuously been in a particular living arrangement for that duration. 
of moving is very high at the start for those in a "new relationship", and only drops below that of divorcees after four years, reaching the same level as married people after almost eight years.

\section{Distance moved}

We hypothesised that divorced/split up people move over shorter distances than married/cohabiting people (Hypothesis 2). Model 1 in Table 2 shows that, on average, divorced people move approximately $15 \mathrm{~km}$ less far than their married counterparts. Hypothesis 2 is not confirmed for split up people in comparison to cohabiters. On the contrary, split up people move longer distances than cohabiters.

We had particular expectations about the distance moved by divorced or split up parents with children. Figure 2 shows the mean moving distances by living arrangement for four parental statuses: not a parent; custody parent (parent of resident children); non-custody parent (parent of non-resident children); and step-parent (not a parent, but living with partner's children in the household). Firstly, we compared bars between the categories "married" and "divorced". This comparison confirms that divorced parents with children move much shorter distances than their married

Fig 2: $\quad$ Mean moving distance in kilometres per parental status; by living arrangement $(\mathrm{N}=6,921)$

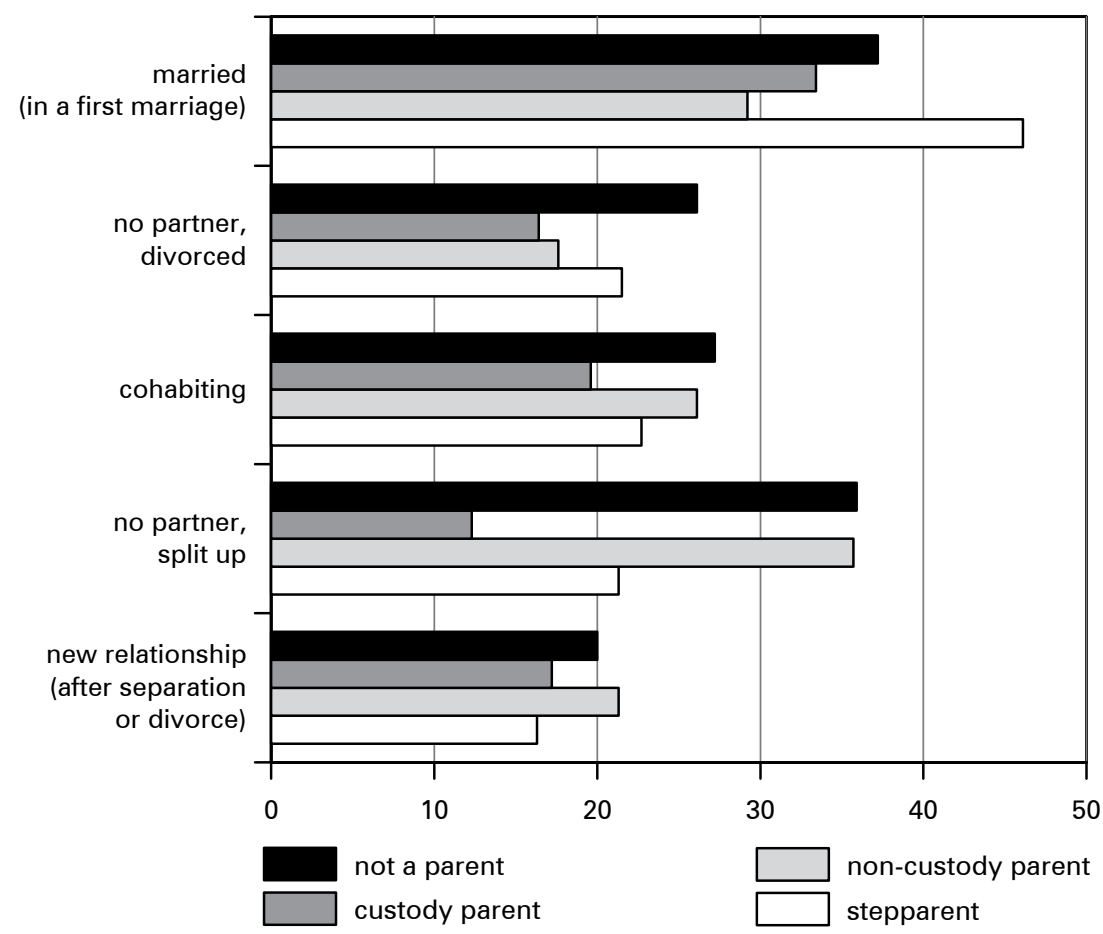

Source: BHPS, own calculations 


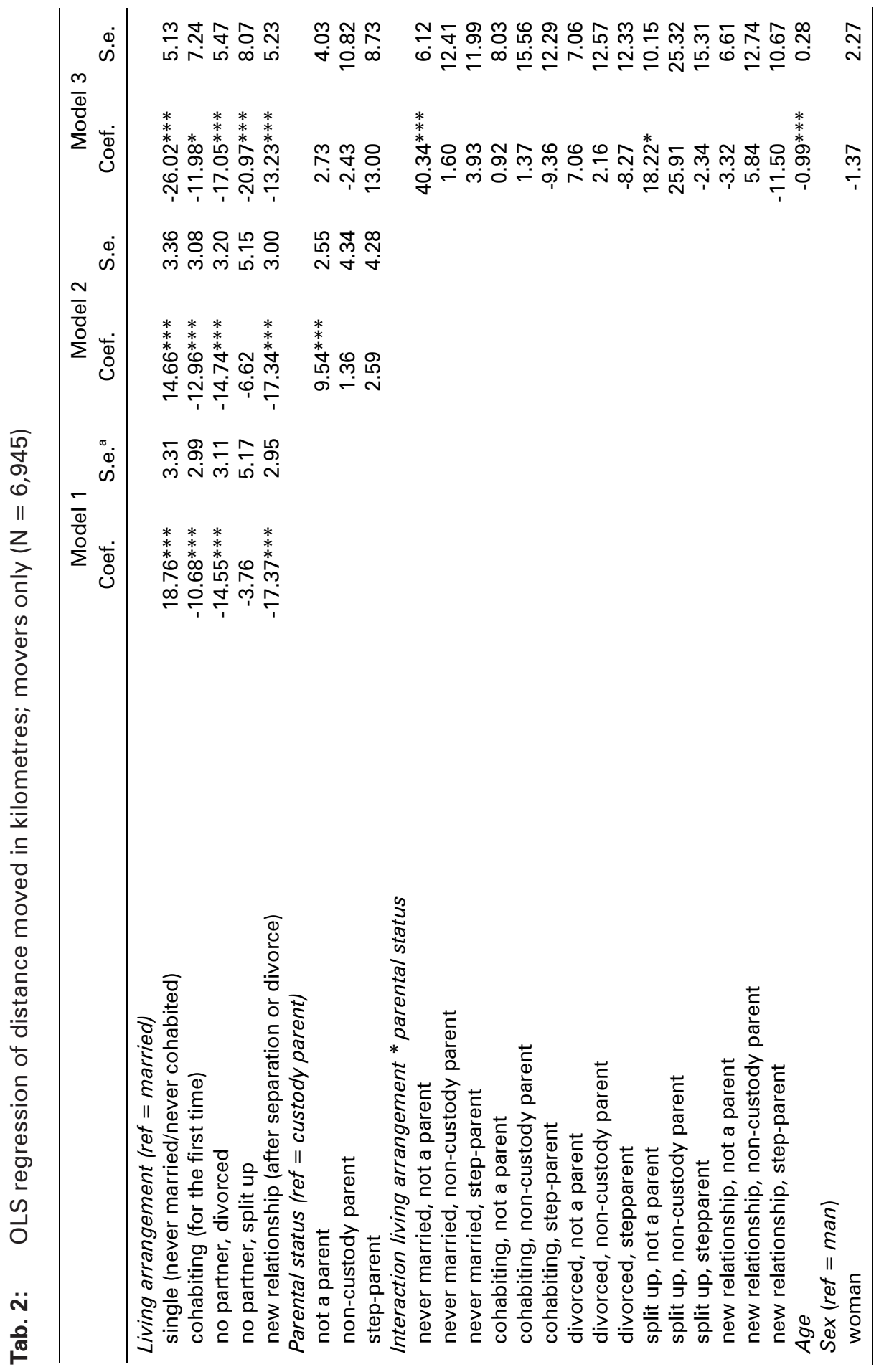




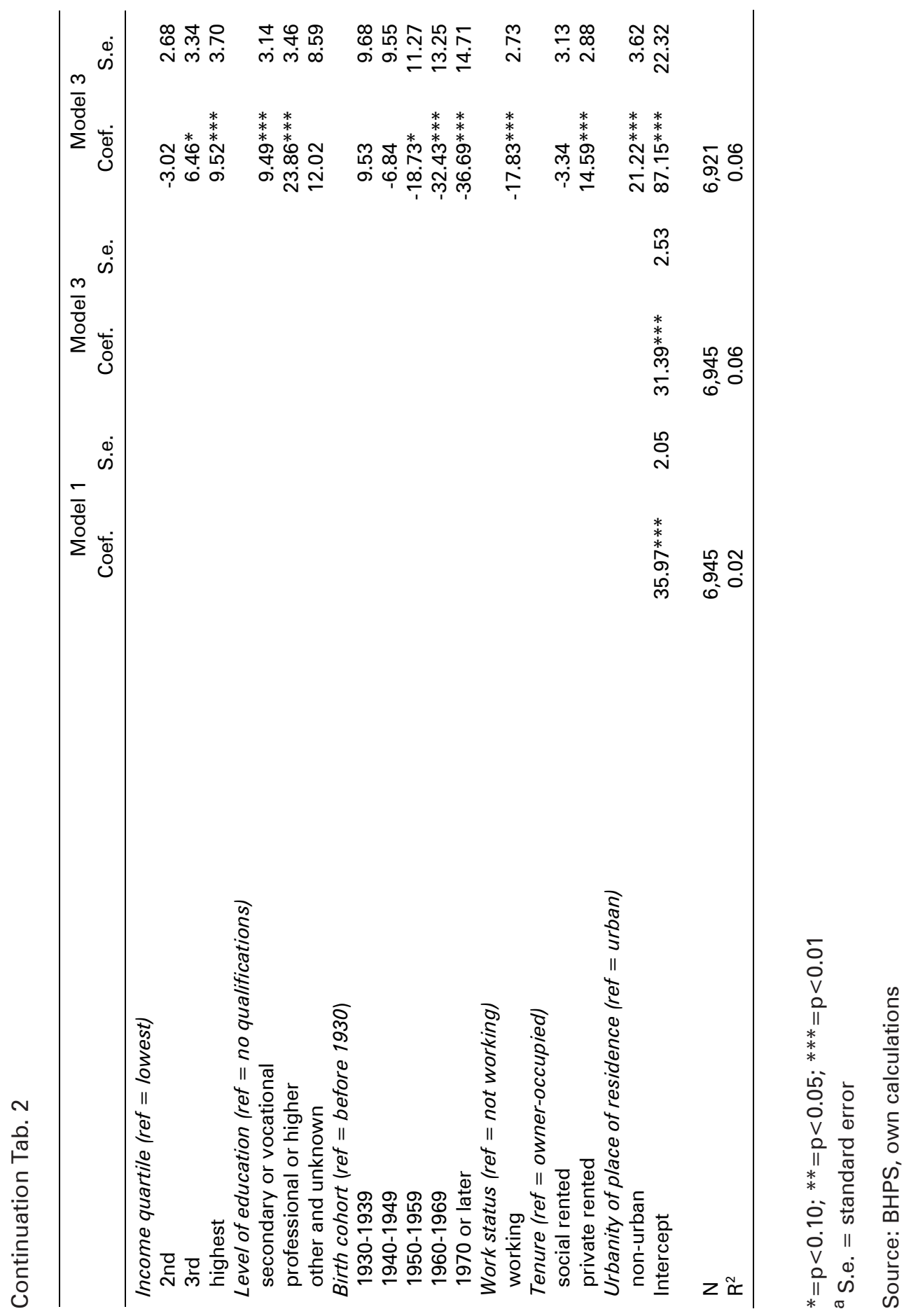


counterparts. This is true for both custody and non-custody parents. Divorced custody and non-custody parents also move over shorter distances than their divorced counterparts who are not parents. When we look at the distance moved of split-up custody parents compared to cohabiting custody parents, we see that the former move shorter distances, which confirms our hypothesis. But the hypothesis is not confirmed for non-custody parents. They are apparently not restricted in their moving distance by their non-custody parenthood.

The question is whether the results found in Figure 2 are caused by living arrangements and parental statuses, or whether there are other underlying causes. In Model 3 in Table 2 we included an interaction effect between living arrangement and parental status, and we controlled for a range of background variables. To make the total regression effects easier to interpret, we plotted them in Figure 3 (distances are all compared to the moving distance of married parents living with their children, whose distance is set at $0 \mathrm{~km}$ ). The figure shows that divorced parents, whether or not they live with their children, are estimated to move over much

Fig 3: $\quad$ Estimated moving distance in kilometres per parental status by living arrangement (based on Model 3 of Table 2) (all distances relative to the base category "married, custody parent") $(\mathrm{N}=6,921)$

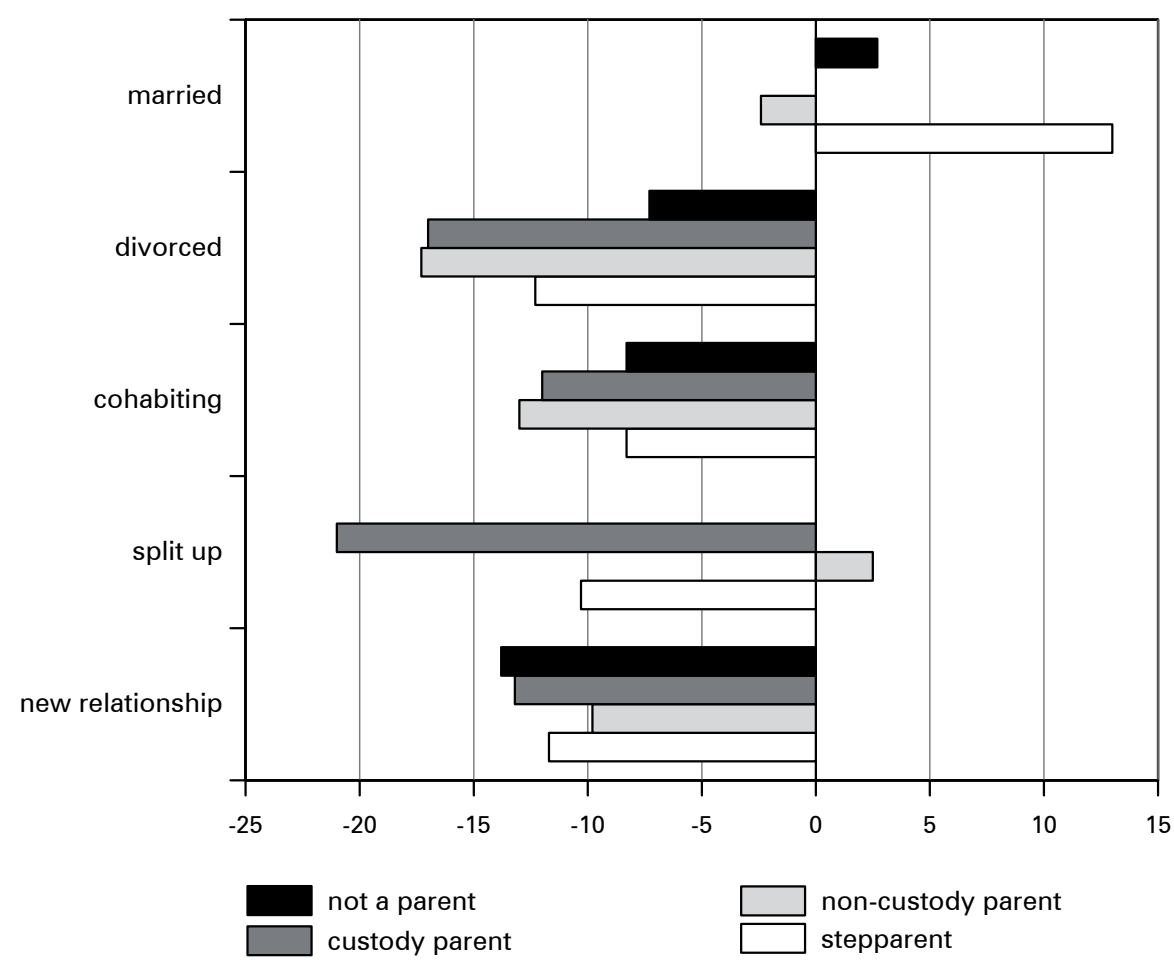

Source: BHPS, own calculations 
smaller distances than their married counterparts. As in the bivariate result, this does not hold for cohabiting versus split-up non-custody parents, but it does hold for custody parents. Thus, the effects of living arrangement and parental status on moving distance are fairly robust.

People in a new relationship also move over relatively short distances. In Model 1 of Table 2, they were actually found to move over the shortest distances of all living arrangements, on average 17 kilometres shorter than the average moving distance of married people. When we control for the interaction between living arrangement and parental status, and for background variables (Model 3 of Table 2), the main effect of living in a new relationship decreases, but the moving distances remain relatively short for all parent statuses (Fig. 3). This may mean that either they move only a short distance to the new partner, and/or that any subsequent moves together with the new partner are over short distances. This may partly be due to one or both of the new partners having local ties to children from a previous relationship (or other local ties such as work).

\section{Direction of moves}

We expected people who split up or divorce to move to cities more often than those who cohabit or are married (Hypothesis 3 ). Table 3 shows the results of an analysis of the moving direction for movers who lived in non-urban Local Authority Districts (LADs) before union dissolution. The coefficients express the probability of moving to an urban LAD (called "city" hereafter) compared to moving within the same or to another non-urban LAD. Model 1 shows that compared to the married, the probability of moving to a city rather than within the non-urban area is significantly higher for all groups. Controlling for duration of living arrangement in Model 2 shows that with increasing duration, the probability of moving to a city decreases, and that only cohabiters are more likely than the married to move to a city.

In Model 3 we also controlled for background variables and we introduced interaction terms between duration and living arrangement. This reduces the main effects of living arrangement even further and all are now insignificant. Of the interaction effects only the effect of splitting up and duration is significant, indicating that for those who split up, the probability that they move to a city increases over time. Overall, we have to conclude that living arrangement is a poor predictor of moving to a city (or, alternatively, that our operationalisation of "city" is poor). The control variables show that the probability of moving to a city is strongly influenced by other factors: level of education and housing tenure (home ownership, private rent, social rent) of the destination dwelling. These two effects support two elements of our explanation for why cities may be attractive to people after union dissolution. The effect of a high level of education is probably due to the concentration of highskill jobs in cities, and to the urban lifestyle often appreciated by those with a higher level of education. The strong effect of housing tenure is probably due to the ample supply of affordable (rented) housing that cities offer.

In short, Hypothesis 3, which states that divorce and separation lead to an increased probability of moving to a city, is only confirmed in the model where we do 
422 - Peteke Feijten, Maarten van Ham

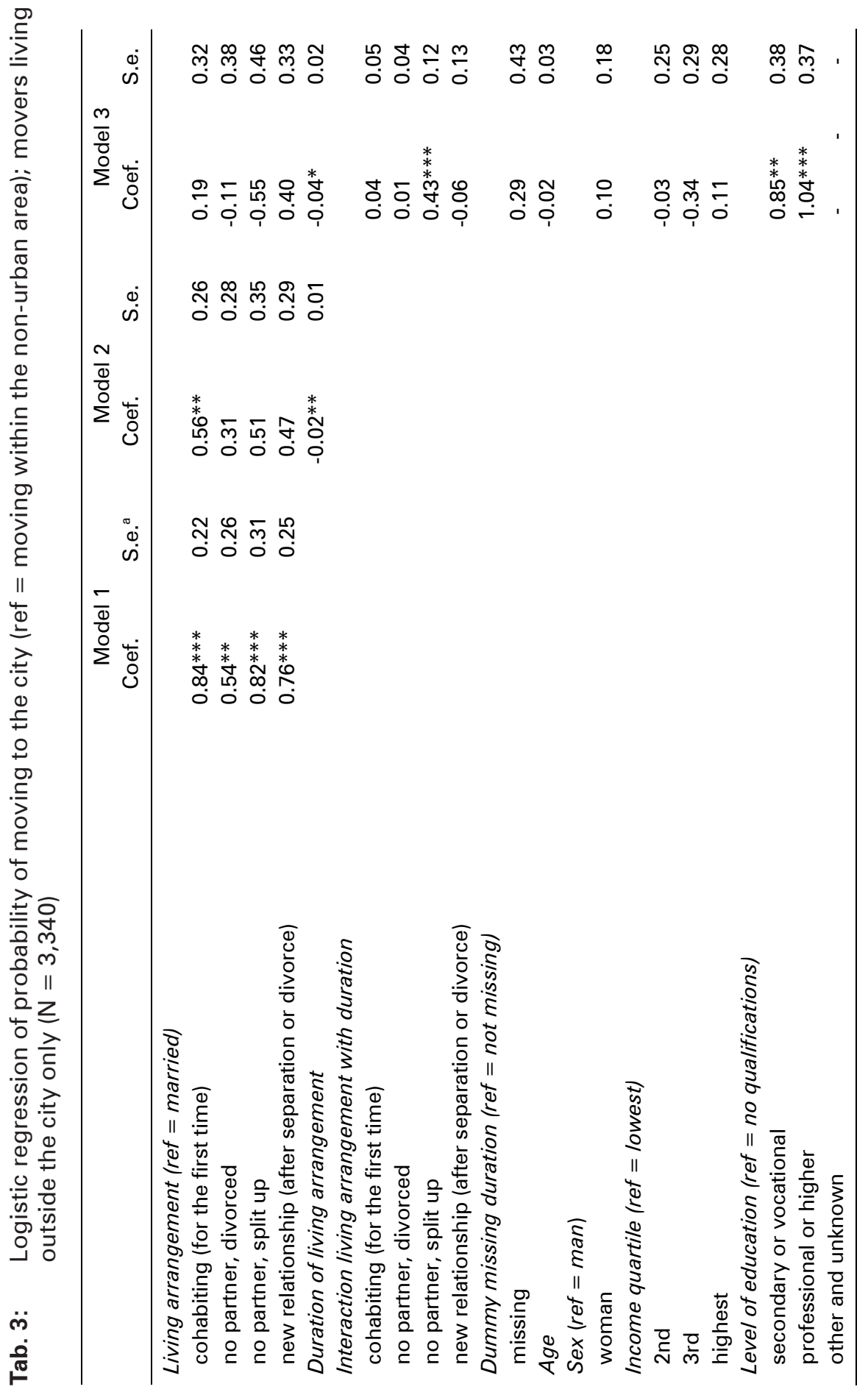



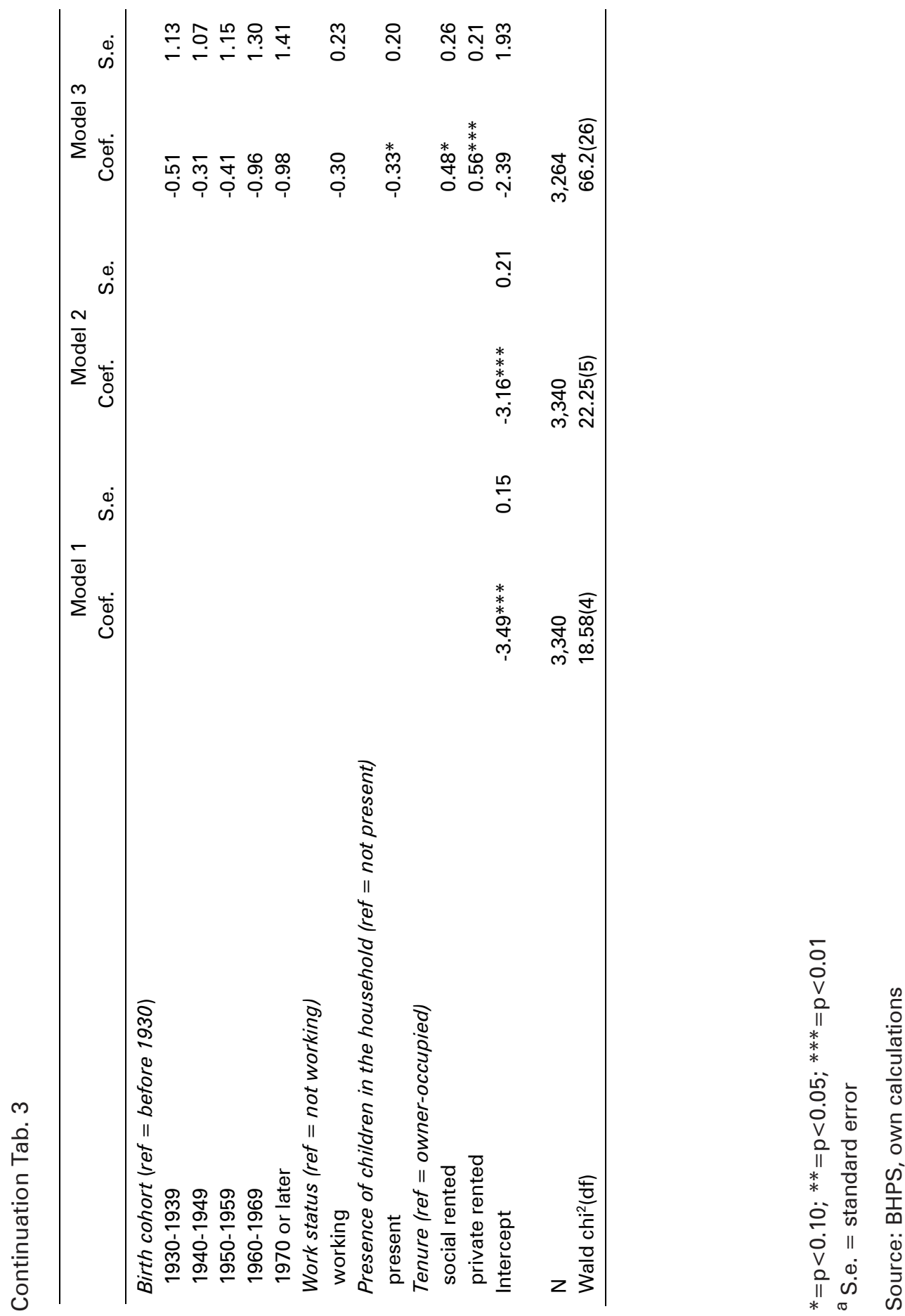
not control for background variables. The only effect that remained after controlling for background variables was that for "split up". After splitting up, former cohabiters are effectively single again, and it is well known that this group is concentrated in cities (Hall/Ogden 2003).

People who form a new relationship after divorce or splitting up are also more likely to move to a city than married people (Model 1 in Table 3). In Models 2 and 3, when duration of the living arrangement is added, it can be seen that the main effect of "new relationship" becomes insignificant, and that the duration effects (main and interaction) are negative. This indicates that re-partnered people have a higher chance of moving to a city than married people, especially at the beginning of a new relationship, but not after some time. It seems that the move made to join the new partner is often into a city, but that this does not apply to subsequent moves. We also modelled the probability of moving out of the city, but the effects differed little between living arrangements.

\section{$5 \quad$ Conclusion and discussion}

We know from previous research that divorce has a disruptive effect on the housing careers of those involved, often leading to downward moves on the housing ladder (Feijten 2005a/b). Much less is known about the geographies of residential mobility after union dissolution. This paper aimed to fill that gap and focussed on three issues: the spatial aspects of housing careers, including the occurrence of moves, distances moved, and the destinations of moves after union dissolution; the effects of union dissolution for both the married and those cohabiting; and the effect on spatial careers of re-partnering after union dissolution.

We showed that union dissolution has a significant effect on the mobility rate and the moving distance of those involved. A period of frequent moving begins for many at the moment of divorce or split up. The move out of the communal home is the first move, but frequently not the last. For many, the first move is into temporary accommodation, which means that one or more follow-up moves have to be made before finding suitable, more permanent housing. A (sharp) decrease in resources, a change in housing preferences, and the disappearance of economies of scale all contribute to the need to make adjustment moves before a new satisfactory housing situation is attained. Those who split up are also very mobile, but so are those who cohabitate, and therefore the gap between these two categories is smaller than between divorcees and married people.

The spatial behaviour of divorced movers differs distinctly from that of married movers. Firstly, the average moving distance is shorter for divorcees than for married people. We attributed this to a preference to stay in the same area, as this causes the least disruption of daily life in a time that is already stressful, and allows people to keep most of their location-specific capital. Divorced parents with children (both custody and non-custody parents) were estimated to move over the shortest distances, both when background characteristics were controlled for, and when they were not. Parents have a strong incentive to stay close to where they 
lived before the break-up, probably to expose the children to as little change in their daily lives as possible. Also, if both parents wish to maintain close contact with their children, physical proximity is essential, and this is reflected in the short moving distance that we found for this group. A short moving distance was also found for custody parents after splitting up from cohabitation. Interestingly, non-custody parents move over much longer distances after splitting up, and these are comparable to the distances moved by childless married couples. A possible explanation is a lower level of commitments among unmarried non-custody parents, allowing them to move more freely. As expected, moves to the city were found to be made more often by divorced people than by married people, although this was largely attributable to composition effects in terms of education and tenure. The probability of moving to a city remained high among separated cohabiters, but this was also the case for cohabiters.

Distinguishing between marriages and cohabitations, and the dissolution of these two types of unions, led to some interesting results. Firstly, divorcees behaved very differently than their married counterparts. The divorced move often, but only over short distances. The married move very little, but if they do, they do so over much longer distances. Although we have no information on motivations for moving, it is likely that many such moves are for job-related reasons (as long-distance moves often are; see for example Clark/Dieleman 1996 or Mulder/Hooimeijer 1999). Secondly, those who split up from their cohabitation partner did not differ much in their mobility behaviour from those who cohabited. Both cohabitation and splitting up signal a highly-mobile life phase (even after controlling for age), where people are exploring their possibilities and shaping their identity in terms of housing and residential location. It seems that breaking up is not so much a disruption of the housing career, but merely one event in a series of life events that opens up new opportunities. Because the commitment made to a cohabiting partner is on average weaker than to a married partner, the consequences of splitting up are less severe in many respects, and our analysis confirms this for the spatial career.

A unique contribution of this study was the inclusion of those who started a new relationship after a split up or divorce. We found that their mobility remains quite high (compared to when they were divorced or split-up). But with increasing duration of the new relationship, the mobility rate decreases rapidly, starting to resemble that of people married for the first time. This corresponds to our expectations. Concerning the distance moved, the results showed that the average moving distance of those who are in a new relationship is among the shortest of all types of living arrangements. Perhaps new partners are often found locally, which takes away the necessity to move over a longer distance in order to move in with the new partner. Also, once the new relationship is formed, long moving distances are rare. This may be because divorced and split up people who form a new relationship still have local ties, especially when there are children from a previous relationship. When the new partner is also divorced/split up, the new couple is even more restricted in where they can move because they both have local ties (see also Stjernström 2009a/b). Concerning moving direction, it was found that at the start of the new relationship, moves to a city are made more frequently than by people in a first marriage, but 
the likelihood of moving to a city quickly drops, gradually approaching the level of people married for the first time. The differences between living arrangements disappear when we control for background variables. Our hypothesis is thus partly confirmed.

The results of this study have wider implications for our understanding of residential mobility and migration on the level of households and society. People who are going through a divorce are more mobile than those who are married. A high level of divorce in a society therefore results in higher levels of residential mobility among the divorced population compared to the married population, and increased demand for housing. Most of those in a union dissolution process are less likely to move over longer distances because of local ties, especially when there are children from a previous marriage. These local ties are likely to restrict workers' willingness to accept jobs over longer distances, potentially hampering occupational mobility. For society as a whole, a high level of divorce, and a large number of people who have experienced divorce, is likely to reduce the spatial flexibility of the labour force.

Our findings also have consequences for future mobility and family research. They show that standard categorisations of households, which do not include whether people have been previously married/have previously cohabited, might bias the outcomes of mobility studies. Future work should distinguish between marriage and cohabitation, and take people's relationship histories into account. Our results also suggest that future research needs to take more note of whether there are children in the household from previous relationships (of both partners) or whether there are children living outside the household (for non-custody parents). This issue also touches upon how we conceptualise households and families. Most current studies do not recognize that daily reality can be quite complicated in many households including divorced parents and that these complexities can influence the mobility, housing and work careers of those involved.

\section{References}

Aassve, Arnstein; Betti, Gianni; Mazzuco, Stefano; Mencarini, Letizia 2006: Marital Disruption and Economic Well-being: A Comparative Analysis. ISER Working papers: [doi: 10.1111/j.1467-985X.2007.00483.x].

Anthony, Kathryn H. 1997: Bitter Homes and Gardens: The Meanings of Home to Families of Divorce. In: Journal of Architectural and Planning Research 14: 1-19.

Barlindhaug, Rolf; Skjørten, Kirstin 2007: The Involvement of Children in Decisions about Shared Residence. In: International Journal of Law, Policy and the Family 21,3: 373-38 [doi: dx.doi.org/10.1093/lawfam/ebm011].

Boyle, Paul J.; Kulu, Hill; Cook, Thomas; Gayle, Vernon; Mulder, Clara H. 2008: The effect of moving on union dissolution. In: Demography 45,1: 209-222 [doi: 10.1353/ dem.2008.0000].

Brown, Lawrence A.; Moore, Eric G. 1970: The intra-urban migration process: A perspective. In: Geografiska Annaler B,52: 1-13. 
Buck, Nick 2000: Using panel surveys to study migration and residential mobility. Researching Social and Economic Change. In: Rose, David (Eds.): The uses of household panel studies. London: Routledge: 250-272.

Bumpass, Larry L.; Lu, Hsien Hen 2000: Trends in cohabitation and implications for children's family contexts in the United States. In: Population Studies 54,1: 29-41.

Clapham, David; Kintrea, Keith; McAdam, Gordon 1993: Individual Self-provision and the Scottish Housing System. In: Urban Studies 30: 1355-1369 [doi: 10.1080/00420989320081301].

Clark, William A.; Dieleman, Frans M. 1996: Households and Housing: Choice and Outcomes in the Housing Market. New Brunswick, NJ: Center for Urban Policy Research.

Cohen, Jacob; Cohen, Patricia 1975: Applied Multiple Regression/Correlation Analysis for the Behavioral Sciences. Hillsdale/ New Jersey: Erlbaum.

Coleman, Marilyn; Ganong, Lawrence; Fine, Mark 2000: Reinvestigating remarriage: Another decade of progress. In: Journal of Marriage and the Family 62: 1288-1307.

DaVanzo, Julie 1981: Repeat Migration, Information Costs and Location-Specific Capital. In: Population and Environment 4: 45-73: [doi: 10.2307/27502924].

Dewilde, Caroline; Uunk, Wilfred 2008: Remarriage as a Way to Overcome the Financial Consequences of Divorce - A Test of the Economic Need Hypothesis for European Women. In: European Sociological Review 24,3: 393-407 [doi: 10.1093/esr/jcn025].

Feijten, Peteke 2005a: Union Dissolution, Unemployment and Moving out of Homeownership. In: European Sociological Review 21: 59-71 [doi: 10.1093/esr/jci004].

Feijten, Peteke 2005b: Life events and the housing career: A retrospective analysis of timed effects. Delft: Eburon.

Feijten, Peteke; van Ham, Maarten 2007: Residential mobility and migration of the separated. In: Demographic Research 17,21: 623-654 [doi: 10.4054/Dem.Res.2007.17.21].

Feijten, Peteke; van Ham, Maarten 2010: The impact of splitting up and divorce on housing careers in the UK. In: Housing Studies 25: 483-507 [doi: 1080/02673031003711477].

Feijten, Peteke; van Ham, Maarten 2011: The Impact of Union Dissolution on Moving Distances and Destinations in the UK. IZA working paper 5628.

Feijten, Peteke; Hooimeijer, Pieter; Mulder, Clara H. 2008: Residential Experience and Residential Environment Choice over the Life-course. In: Urban Studies 45,1: 141-162 [doi: 10.1177/0042098007085105].

Feldman, Roberta M. 1990: Settlement-identity: Psychological Bonds with Home Places in a Mobile Society. In: Environment and Behavior 22: 183-229 [doi: 10.1177] 0013916590222002].

Flowerdew, Robin; Al-Hamad, Alaa 2004: The Relationship between marriage, divorce and migration in a British dataset. In: Journal of Ethnic and Migration Studies 30: 339-351 [doi: 10.1080/1369183042000200731].

Gram-Hanssen, Kirsten; Bech-Danielsen, Claus 2006: Home dissolution - What happens after separating? In: European Network for Housing Research Conference 2006: [doi: 10/1080/02673030802020635].

Hall, Ray; Ogden, Philip E. 2003: The rise of living alone in Inner London: trends among the population of working age. In: Environment and Planning A,35: 871-888 [doi: 10.1068/a3549].

Helderman, Amanda C. 2007: Once a homeowner, always a homeowner? An analysis of moves out of owner-occupation. In: Journal of Housing and the Built Environment 22,3: 239-261 [doi:10.1007/s10901-007-9085-6]. 
Huber, Peter J. 1967: The behavior of maximum likelihood estimates under nonstandard conditions. Paper presented at the Fifth Berkeley Symposium on Mathematical Statistics and Probability. California: Berkeley.

Jackson, A. A. 1990: Relationship breakdown: The individual and local authority response. In: Symon, Peter (Eds.): Housing and Divorce: 77-91. Glasgow: Centre for Housing Research, University of Glasgow: 77-91

Jarvis, Sarah; Jenkins, Stephen P. 1999: Marital splits and income changes: Evidence from the British Household panel Survey. In: Population Studies 53: 237-254 [doi: 10.1080/00324720308077].

Kemper, Franz-Josef 1985: Die Bedeutung des Lebenszyklus-Konzepts für die Analyse intraregionaler Wanderungen. In: Kemper, Franz-Josef; Laux, Hans-Dieter; Thieme, Günter (Eds.): Geographie als Sozialwissenschaft: Beiträge zu ausgewählten Problemen kulturgeographischer Forschung: 180-212. Bonn: Dümmlers Verlag.

Kiernan, Kathleen E.; Estaugh, Valerie 1993: Cohabitation: Extra-marital childbearing and social policy. London: Family Policy Studies Centre.

MacDonald, John M.; Lattimore, Pamela K. 2010: Count Models in Criminology. In: Piquero, Alexis Russell; Weisburd, David (Eds.): Handbook of Quantitative Criminology: 683-698. New York: Springer: [doi: 10.1007/978-0-387-77650-7_32].

McCarthy, Peter; Simpson, Bob 1991: Issues in Post-Divorce Housing: Family policy or housing policy? Aldershot: Avebury.

Michelson, William M. 1977: Environmental choice, human behaviour, and residential satisfaction. New York: Oxford University Press.

Mulder, Clara H; Hooimeijer, Pieter 1999: Residential relocations in the life course. In: Van Wissen, Leo J.; Dykstra, Pearl A. (Eds.): Population Issues: An Interdisciplinary Focus: 159-186. Den Haag: NIDI.

Murphy, M. J. 1990: Housing Consequences of Marital Breakdown and Remarriage. In: Symon, Peter (Eds.): Housing and Divorce. Glasgow: Centre for Housing Research, University of Glasgow.

ONS (Office for National Statistics) 2007a: Age and previous marital status, 1961-2003: a. males; Taken from Table 3.2 published in Marriage and divorce statistics - Historical series (FM2 Vol No 16), Table 3.6 in FM2 Vol No's 11 to 23, and Table 3.18 in FM2 Vol No's 24 to 31. London: Office for National Statistics.

ONS (Office for National Statistics) 2007b: ONS 10/12/07, taken from: Table 3.1 published in Birth Statistics 1837-1983 - Historical series FM1 No 13, and Table 3.2 in FM1 Vol No's 11 to 33. London: Office for National Statistics.

Poortman, Anne-Rigt; Fokkema, Tineke 2001: Economische gevolgen van echtscheiding voor mannen en vrouwen in Nederland, 1949-1998. In: Sociale Wetenschappen 44: 69-92.

Rossi, Peter Henry 1955: Why families move: A study in the social psychology of urban residential mobility. Glencoe/Illinois: Free Press.

Schouw, R. J.; Dieleman, Frans M. 1987: Echtscheiding en woningmarkt: een voorstudie naar de complexe relatie tussen echtscheiding en de woningmarkt. Utrecht: KNAG.

South, Scott J.; Crowder, Kyle D. 1998: Avenues and Barriers to Residential Mobility Among Single Mothers. In: Journal of Marriage and the Family 60: 866-877.

Stjernström, Olof 2009a: Distance and Mobility - Some observations among separated and reconstituted households with children in Sweden. Working paper. Umeå: Department of Social and Economic Geography, Umeå University. 
Stjernström, Olof 2009b: Mobility strategies and everyday life for separated and reconstituted households with children - a pre-study. Conference paper for Family, Migration and Housing Conference, Amsterdam, 2-4 April 2009.

Sullivan, Orie/ 1986: Housing Movements of the Divorced and Separated. In: Housing Studies 1: 35-48 [doi: 10.1080/02673038608720561].

Symon, Peter 1990: Marital breakdown, gender and home ownership: The owner-occupied home in separation and divorce. In: Symon, Peter (Eds.): Housing and Divorce. Glasgow: Centre for Housing Research: 110-138.

Van Noortwijk, Lily; Hooimeijer, Pieter; Dieleman, Frans M. 1992: Divorce and the Disruption of the Housing Career. In: Korcelli, Piotr; Van Weesep, Jan (Eds.): Housing and Urban Policy in Transition. Warsaw: PAN IGiPZ: 87-101.

Wasoff, Fran; Dobash, Rebecca Emerson 1990: Moving the family: Changing housing circumstances after divorce. In: Symon, Peter (Eds.): Housing and Divorce. Glasgow: Centre for Housing Research: 139-165.

Watchman, P. O. 1990: Relationship breakdown, homelessness and the law. In: Symon, Peter (Eds.): Housing and Divorce. Glasgow: Centre for Housing Research: 92-108.

Winstanley, Ann; Thorns, David; Perkins, Harvey 2002: Moving House, Creating Home: Exploring Residential Mobility. In: Housing Studies 17: 813-832 [doi: 10.1080/02673030216000].

A German translation of this reviewed and authors' authorised original article by the Federal Institute for Population Research is available under the title "Die Auswirkungen von Scheidung und Trennung auf die räumliche Mobilität in Großbritannien", DOI 10.4232/10.CPOS-2013-10de or URN urn:nbn:de:bib-cpos-2013-10de3, at http://www.comparativepopulationstudies.de.

Peteke Feijten. The Netherlands Institute for Social Research. The Hague, The Netherlands. E-Mail: p.feijten@scp.nl URL: http://www.scp.nl/

Maarten van Ham ( $₫)$. OTB Research Institute for the Built Environment, Delft University of Technology, 2600 GA Delft, The Netherlands. University of St Andrews, UK. IZA Bonn, Germany. E-Mail: m.vanham@tudelft.nl URL: http://www.maartenvanham.nl/ 


\section{Appendix}

Tab. A1: Descriptive variables and statistics (Total $N=74,711$ )

\begin{tabular}{|c|c|c|}
\hline & $\mathrm{N}$ & $\%$ \\
\hline \multicolumn{3}{|l|}{ Move out of owner-occupation } \\
\hline not at risk & 18,570 & $24.9 \%$ \\
\hline at risk & 52,806 & $70.7 \%$ \\
\hline move from owner-occupation to rent & 2,572 & $3.4 \%$ \\
\hline person-years after moving out of owner-occupation & 763 & $1.0 \%$ \\
\hline \multicolumn{3}{|l|}{ Move status } \\
\hline no move & 66,439 & $88.9 \%$ \\
\hline Move & 8,272 & $11.1 \%$ \\
\hline \multicolumn{3}{|l|}{ Move to city status } \\
\hline previous place of residence unknown & 5,143 & $6.9 \%$ \\
\hline not at risk & 20,174 & $27.0 \%$ \\
\hline no move & 45,476 & $60.9 \%$ \\
\hline move to city & 3,655 & $4.9 \%$ \\
\hline move within countryside & 263 & $0.4 \%$ \\
\hline \multicolumn{3}{|l|}{ Living arrangement } \\
\hline single (never married) & 8,410 & $11.3 \%$ \\
\hline married & 49,479 & $66.2 \%$ \\
\hline cohabiting & 5,716 & $7.7 \%$ \\
\hline divorce/separation from marital partner & 6,237 & $8.3 \%$ \\
\hline separation from cohabitation partner & 1,213 & $1.6 \%$ \\
\hline new relationship & 3,656 & $4.9 \%$ \\
\hline \multicolumn{3}{|l|}{ Sex } \\
\hline male & 35,013 & $46.9 \%$ \\
\hline female & 39,698 & $53.1 \%$ \\
\hline \multicolumn{3}{|l|}{ Income quartiles (disposable annual household income) } \\
\hline lowest $(<£ 14,000)$ & 19,003 & $25.4 \%$ \\
\hline 2nd (£14,000 - £22,999) & 18,646 & $25.0 \%$ \\
\hline 3rd (£23,000 - £33,999) & 18,020 & $24.1 \%$ \\
\hline highest $(>=£ 34,000)$ & 19,042 & $25.5 \%$ \\
\hline \multicolumn{3}{|l|}{ Highest completed level of education } \\
\hline below secondary / no education & 15,469 & $20.7 \%$ \\
\hline secondary or vocational & 27,847 & $37.3 \%$ \\
\hline professional or higher & 28,637 & $38.3 \%$ \\
\hline other or unknown & 2,758 & $3.7 \%$ \\
\hline
\end{tabular}


Continuation Tab. A1

\begin{tabular}{|c|c|c|}
\hline & $\mathrm{N}$ & $\%$ \\
\hline \multicolumn{3}{|l|}{ Birth cohort } \\
\hline before 1930 & 2,891 & $3.9 \%$ \\
\hline 1930-1939 & 9,773 & $13.1 \%$ \\
\hline $1940-1949$ & 16,770 & $22.4 \%$ \\
\hline $1950-1959$ & 17,667 & $23.6 \%$ \\
\hline $1960-1969$ & 18,034 & $24.1 \%$ \\
\hline 1970 or later & 9,576 & $12.8 \%$ \\
\hline \multicolumn{3}{|l|}{ Labour market status } \\
\hline not working & 22,025 & $29.5 \%$ \\
\hline working & 52,686 & $70.5 \%$ \\
\hline \multicolumn{3}{|l|}{ Parent and child-in-household status } \\
\hline no children in household, not parent & 43,808 & $58.6 \%$ \\
\hline no children in household, parent & 2,360 & $3.2 \%$ \\
\hline children in household, not parent & 5,018 & $6.7 \%$ \\
\hline children in household, parent & 23,525 & $31.5 \%$ \\
\hline \multicolumn{3}{|l|}{ Tenure } \\
\hline owner-occupied & 57,084 & $76.4 \%$ \\
\hline social rented & 12,155 & $16.3 \%$ \\
\hline private rented or other & 5,472 & $7.3 \%$ \\
\hline \multicolumn{3}{|l|}{ Urban indicator } \\
\hline urban & 20,437 & $27.4 \%$ \\
\hline non-urban & 49,131 & $65.8 \%$ \\
\hline \multirow[t]{2}{*}{ unknown } & 5,143 & $6.9 \%$ \\
\hline & Mean & s.d. ${ }^{a}$ \\
\hline Distance (in kilometres, for movers only) & 35.4 & 83.1 \\
\hline Living arrangement duration (in years) & 17.0 & 14.6 \\
\hline Age (in years) & 43.7 & 13.3 \\
\hline
\end{tabular}

${ }^{\text {a }}$ s.d. = standard deviation

Source: BHPS, own calculations 


\section{Comparative Population Studies - Zeitschrift für Bevölkerungswissenschaft}

wWw.comparativepopulationstudies.de

ISSN: 1869-8980 (Print) - 1869-8999 (Internet)

Published by / Herausgegeben von

Prof. Dr. Norbert F. Schneider

Federal Institute for Population Research

D-65180 Wiesbaden / Germany

Managing Editor /

Verantwortlicher Redakteur

Frank Swiaczny

Assistant Managing Editor /

Stellvertretende Redakteurin

Katrin Schiefer

Language \& Copy Editor (English) /

Lektorat \& Übersetzungen (englisch)

Amelie Franke

Copy Editor (German) /

Lektorat (deutsch)

Dr. Evelyn Grünheid

\section{Layout / Satz}

Beatriz Feiler-Fuchs

E-mail: cpos@bib.bund.de

\author{
Scientific Advisory Board / \\ Wissenschaftlicher Beirat \\ Jürgen Dorbritz (Wiesbaden) \\ Paul Gans (Mannheim) \\ Johannes Huinink (Bremen) \\ Marc Luy (Wien) \\ Clara H. Mulder (Groningen) \\ Notburga Ott (Bochum) \\ Peter Preisendörfer (Mainz)
}

\section{Board of Reviewers / Gutachterbeirat} Martin Abraham (Erlangen)

Laura Bernardi (Lausanne) Hansjörg Bucher (Bonn) Claudia Diehl (Göttingen) Andreas Diekmann (Zürich) Gabriele Doblhammer-Reiter (Rostock) Henriette Engelhardt-Wölfler (Bamberg) E.-Jürgen Flöthmann (Bielefeld) Alexia Fürnkranz-Prskawetz (Wien) Beat Fux (Zürich) Joshua Goldstein (Rostock) Karsten Hank (Köln) Sonja Haug (Regensburg) Franz-Josef Kemper (Berlin) † Michaela Kreyenfeld (Rostock) Aart C. Liefbroer (Den Haag) Kurt Lüscher (Konstanz) Dimiter Philipov (Wien) Tomáš Sobotka (Wien) Heike Trappe (Rostock) 